\title{
RESPON KELUARGA TERHADAP PERUBAHAN FUNGSI POKOK KELUARGA AKIBAT COVID - 19 DI NEGERI HUKURILA KOTA AMBON
}

\author{
Feky Manuputty, Wellem R. Sihasale \\ Program Studi Sosiologi Fakultas Ilmu Sosial dan Ilmu Politik \\ Universitas Pattimura \\ manuputty1961@gmail.com
}

\begin{abstract}
Abstrak
Pandemik covid-19 memberi dampak yang sangat besar terhadap peran dan fungsi keluarga. Terjadinya penurunan ekonomi keluarga secara drastis, keterbatasan dalam bersosialisasi dan berinteraksi langsung dengan masyarakat sekitar, juga perubahan paradigma pendidikan. Tidak hanya secara luas, namun begitu juga bagi masyarakat di Negeri Hukurila, Kecamatan Leitimur Selatan, Kota Ambon. Untuk itu penelitian ini bertujuan mengetahui dan menjelaskan respons keluarga terhadap perubahan fungsi pokok keluarga akibat pandemik covid-19 di Negeri Hukurila. Sumber data yang digunakan melalui wawancara dan observasi. Informan dalam penelitian ini berjumlah lima belas orang, yang dipilih menggunakan purposive sampling. Penelitian ini menemukan perubahan yang mencolok dalam lima fungsi keluarga, serta bagaimana respons keluarga terhadap perubahan tersebut dalam kebiasaan baru di masa pandemik covid-19.
\end{abstract}

Kata Kunci: Respos Keluarga, Perubahan Fungsi Keluarga, Covid-19.

\begin{abstract}
Pandemic covid-19 affects huge family roles and functions. This has resulted a drastic decline in the family economy, limitations in socializing and interacting directly with the people around them, as well as the educational paradigm. Not only globally, but also to the people of the land of Hukurila, The Southern Leitimur District, The City of Ambon. For that purpose, research aims to know and explain the family's response to the fundamental change of family function brought about by the covid-19 pandemic in the land of Hukurila. The data source used through interviews and observations. Fifteen people were accounted for the informants in this study, they have been selected using purposive sampling. The study found a significant change in the five functions of the family, as well as how the family responded to the change in the new custom of the covid-19 pandemic.
\end{abstract}

Keywords: Family's Response, Change in Family Function, Covid-19. 
1. Pendahuluan.

Perubahan sosial merupakan gejala yang melekat dimasyarakat yang dapat diketahui dengan membandingkan keadaan masyarakat pada suatu waktu. Misalnya di beberapa daerah masyarakat Indonesia umumnya (pada masa lalu), suami merupakan posisi yang sangat dominan dalam berbagai urusan dalam kehidupan keluarga, sehingga apabila suami tidak bekerja atau tidak mempunyai penghasilan, suatu keluarga secara ekonomi akan mengalami lumpuh. Dalam perkembanganya, pada masyarakat modern sekarang suami tidak selalu merupakan posisi yang menentukan jalannya kehidupan keluarga.

Laju perkembangan kehidupan sosial tidak selalu sama antara suatu masyarakat dengan masyarakat lain. Misalnya antara masyarakat desa dengan masyarakat kota. Demikian juga antara masyarakat yang terisolasi (terasing) dengan masyarakat terbuka mempunyai hubungan sosial dengan masyarakat lain. Masyarakat terisolasi mempunyai laju perubahan yang sangat lambat, sehingga sering disebut masyarakat statis. Disebut masyarakat statis tentu saja bukan berarti tidak mengalami perubahan sama sekali atau mengalami stagnasi (kemandegan), tetapi perubahan yang terjadi berlangsung dengan lambatnya sehingga hampir tidak menunjukkan gejala perubahan. Sedangkan masyarakat yang terbuka hubungannya dengan masyarakat luas mengalami perubahan yang berlangsung dengan cepat, sehingga sering disebut dengan masyarakat dinamis. Perubahan sosial yang terjadi dalam masyarakat menimbulkan ketidaksesuaian antara unsur sosial yang ada dalam masyarakat. Dengan kata lain, perubahan sosial akan mengubah struktur dan fungsi dari unsurunsur sosial dalam masyarakat.Dengan demikian,perubahan sosial dalam masyarakat mengandung ketidaksesuain diantara unsur-unsur sosial yang saling berbeda dalam masyarakat sehingga menghasilkan suatu pola kehidupan yang tidak serasi fungsinya bagi masyarakat yang bersangkutan. 
Struktur sosial merupakan jalinan diantara unusr-unsur sosial yang pokok dlam masyarakat yang menunjukan pada bentuk seluruh jaringan hubungan antara individu daalam masyarakat dimana terjalin interaksi dan kommonikasi sossial. Sedangkan sistem sosial menunjukan pada bagaimana hubungan antara unsur-unsur sosial dlam masyarakat sehingga memebentuk suatu kebulatan (totalitas) yang berfungsi,Perubahan Sosial dapat dikatakan bahwa perubahan pada segi structural masyarakat seperti pola-pola perilaku dan interaksi antara anggota masyarakat,perubahan pada segi kultur masyarakat seperti nilainilai,sikap-sikap,serta norma-norma masyarakat. Perubahan diberbagai tingkat kehidupan manusia mulai dari tingkat individual, keluarga, masyarakat, hingga ketingkat masyarakat dunia.

Keluarga merupakan kelompok sosial yang terkecil terdiri dari suami,istri beserta anak-anaknya yang belum menikah. Keluaraga tersebut lazimnya disebut rumahtangga,yang merupakan unit terkecil dalam masyarakat sebagai wadah pergaulan hidup. Suatu sistem sosial yang pada pokoknya mencangkup kepercayaan,perasaan,tujuan,dan kaidah-kaidah kedudukan dan peranan (Soekanto,2004:1).

Keluarga adalah suatu sistem interaksi yang mana setiap komponennya memiliki batasan yang selalu berubah dan derajat ketahanan untuk berubah yang bervariasi. Keluarga akan melalui suatu proses perubahan yang akan menghasilkan tekanan terhadap anggotanya tumbuh dan berkembang. Keluarga harus mempersiapakan diri untuk merespon perubahan kebutuhan anggotannya dari waktu ke waktu,bersiap untuk kejadian yang tidak direncanakan yang melibatkan anggotanya. Tekanan yang berasal dari luar sistem. Secara nyata perubahan struktur keluarga ini bisa dilihat dari institusi keluarga saat ini. Seiring dengan perkembangan zaman,status dan peran antara suami-istri pada beberapa keluarga sama/sederajat dalam peenuhan kebutuhan hidup seharihari,aktualisasi diri diranah publik,sampai dengan perkembangan karir. Perubahan fungsi ini akhirnya berakibat pada perubahan struktur keluaga. Menurut Lippit yang dikutip oleh Merril dan Elliot dalam Khairuddin (1997:5) bahwa "pendorong bagi perubahan keluarga adlah berkembangnya kebudayaan materi,tingkat penemuan dan inovasi teknologi,perbaikan komonikasi dan meluasnya induatrialisasi dan urbanisasi". Perubahan sosial yang cepat sebagai konsekuensi modernisasi,industrialisasi,dan kemajuan teknologi telah membawa perubahan nilai-bilai kehidupan. Perubahan ini dapat 
dilihat dari kecenderungan perubahan pola keluarga dari suatu pola keluarga tradiosanal ke pola keluarga modern. Perubahan nilai nilai sosial dapat merupakan sala satu bentuk gangguan kestabilan keluarga. Pergeseran dari masyarakat tani,buta huruf,ke masyarakat melek huruf terpesialisasi dan terindustrialisasi telah mengubah anak dari modal ekonomi. Dewasa ini banyak dijumpai jumlah keluarga yang jumlah anggotanya sedikit,adanya pendapat tradisonal bahwa"banyak anak banayak rezeki" dan keluarga besar adalah suatu pelayanan leluhur terhadap masyarakat telah diganti dengan pendapat "banyak anak banyak susah" dan melahirkan banyak anak adalah tindakan yang tidak bertanggung jawab terhadap anak dan masyarakat. Jadi,perubahan teknologi,perubahan ekonomi,perubahan nilai,semuanya terlibat dalam perubahan besar keluarga. Penerapan teori structural-fungsional pada keluarga oleh Parsons adalah sebagai reaksi dari pemikiran-pemikiran melunturnya atau berkurangnya fungsi keluarga karena adanya modernisasi. Bahkan menurut Parsons,fungsi keluarga pada zaman modern,terutama dalam hal sosialisasi anak dan tension management untuk masing-masing anggota keluarga,justru akan semakin terasa penting (Puspitawati,2009:5). Hal yang sama dijumpai pada masyarakat (Negeri) yaitu ; Negeri Hukurila pada awal observasi ditemukan fungsi ekonomi,dimana keluarga bukan lagi unit yang mampu memenuhi kebutuhan sendiri seperti masa lalu yaitu suami berperan mencari nafkah untuk kebutuhan keluarga (konsumtif) dan istri tinggal di rumah mengerjakan pekerjaan rumah tangga dan menjaga serta merawat anak-anak, malah sekarang peranan perempuan/istri sudah membantu suami mencari nafkah diluar rumah misalnya berjualan di pasar mardika (papalele) berupa buah-buahan ikan segar maupun ikan asar/asapan, begitu juga ada yang berjualan di tempat wisata. Selain itu ada anak-anak mereka yang sudah dewasa baik lakilaki maupun perempuan juga turut membantu orang tua mereka, misalnya menjadi tukang ojek, membantu ayah pergi melaut memancing ikan tuna, sedangkan anak perempuan membuat kua untuk berjualan di tempat wisata dan berjualan keliling di Negeri.

Sekarangan ini, keluarga sedang mengalami disfungsi dikarenakan munculnya wabah penyakit Covid-19. Pada bulan Desember 2019, pneumonia yang tidak dapat dijelaskan ditemukan di Wuhan, Cina, dan penyakit ini menyebar dengan cepat ke seluruh Negeri (Lin, 2020). Pada tanggal 7 Januari 2020, China mengidentifikasi pneumonia yang tidak diketahui etiologinya tersebut sebagai jenis baru coronavirus (novel coronavirus). Pada awal tahun 2020 NCP mulai menjadi pendemi global dan menjadi masalah kesehatan 
di beberapa negara di luar RRC (Safrizal, 2020). Semenjak kemunculannya pertama kali di Kota Wuhan, penularan Covid-19 melesat begitu cepat diberbagai negara, sehingga menggemparkan masyarakat Internasional. Organisasi Kesehatan Dunia telah menyatakan Covid-19 sebagai pandemi (Nolan, 2020). Deklarasi WHO ini dikuatkan oleh banyaknya penelitian ahli yang menunjukan bagaimana cepatnya Covid-19 menginfeksi dan menular dari satu tubuh manusia ke tubuh manusia lainnya. Penularan Covid-19 yang sangat cepat menjadi ciri khas atau karakteristik yang membedakannya dengan penyakit sejenisnya yang pernah muncul. Memang karakter virus ini sangat menular, virus ini cepat menyebar dan terus berkembang dalam populasi manusia (Liu, 2020). Berdasarkan data yang diterima WHO dari otoritas nasional setempat pada 9 Juni 2020, sudah lebih dari 7 juta kasus Covid-19 dan lebih dari 400.000 kematian (WHO, 2020). Sedangkan data sebaran pandemi Covid 19 secara global, yaitu menyebar di 216 Negara dengan rincian kasus yang terkonfirmasi 8.184.867 dan meninggal 443.461(“Gugus Tugas Percepatan Penanganan Covid 19," n.d.). Dengan demikian, sejak pertama kali kemunculannya di Kota Wuhan, jumlah manusia yang terjangkit dan terinfeksi Covid-19 di seluruh dunia secara kumulatif terjadi peningkatan signifikan setiap harinya.

Tidak berbeda jauh dengan kondisi di negara lain, melonjaknya angka penularan Covid-19 juga terjadi di Indonesia. Bila dirunut kembali ke belakang, sejak pertama kali ditemukannya dua kasus warga Indonesia yang terpapar Covid 19, hingga per 10 Juni 2020 jumlah penderita Covid-19 yang terkomfirmasi positif tidak kurang dari 42.762 orang dengan rincian 16.798 sembuh dan 2339 meninggal dunia (JNN, n.d.). Kecenderungan meningkatnya infeksi Covid-19 di Indonesia tidak hanya berdampak buruk pada masalah kesehatan, tetapi juga berpengaruh dan berimplikasi negatif terhadap bidang kehidupan lainnya, seperti ekonomi, pendidikan, agama, dan sosial budaya. Misalnya dampak Covid-19 terhadap perekonomian Indonesia, yaitu adanya kebijakan efisiansi produksi perusahaan yang disusul dengan terjadinya gelombang PHK besarbesaran, sehingga melahirkan jutaan pengangguran. Ini juga memicu kekhawatiran akan terjadinya krisis ekonomi dan resesi (Nicola, 2020). Tidak lama, daya beli masyarakat pun ikut merosot yang membuatnya kesulitan dalam memenuhi kebutuhan hidup. Di masa pandemi Covid-19 ini semakin banyak orang yang frustasi atau stres menghadapi memburuknya situasi dan kondisi perekonomian. Akibat Covid-19 pendidikan pun berubah paradigma, berhubung aktivitas pembelajaran bergeser dari lingkungan sekolah 
yang sebelumnya berbasis tatap muka (klasikal) menjadi virtual (dunia maya). Diharapkan dengan penutupan sekolah selama pandemi dapat memutus rantai penularan (Simon, 2009). Selain meniadakan kegiatan pendidikan di sekolah, Covid-19 juga mengganggu kegiatan sosial, budaya, dan keagamaan. Penularan Covid-19 melalui kontak fisik juga menghalangi manusia dalam mengaktualisasikan dirinya sebagai mahkluk sosial untuk berinteraksi.

Wabah Covid-19 sangat memberikan efek yang luar biasa terhadap peran dan fungsi keluarga di dalam masyrakat.seperti yang dialami oleh warga desa Hukurila,kecamatan leitimur selatan Kota Ambon. Dimana terjadinya penurunan ekonomi keluarga yang sangat drastis,keterbatasan dalam bersosialisasi dan berinteraksi langsung dengan masyarakat sekitarnya dikarenakan "Social Distancing" atau jaga jarak,serta kegiatan sekolah "belajar mengajar" yang harus diambil alih oleh orang tua sebagai guru sekalian murid dalam situasi belajar "Daring" dirumah, begitu juga aktivitas beribadah ditiadakan dan setiap anggota keluarga mau keluar rumah harus mematuhi regulasi yang sudah diputuskan oleh pemerintah, baik pemerintah Pusat, Pemerintah Daerah dan Pemerintah Kota, sehingga semua masyiarakat mau melakukan aktivitas di luar rumah harus mematuhi aturan-aturan seperti memakai masker, menjaga jarak, jangan berkerumun, dan mencuci tangan.

\section{Metode Penelitian.}

Sumber data dalam penelitian kualitatif yaitu dengan cara wawancara, observasi, foto atau dokumentasi dan lainnya. Agar informan yang diperoleh dapat maksimal maka penelitian ini mennggunakan sumber: Data sekunder, dilakukan untuk mencari data dan informasi, serta referensi yang berkaitan dengan lama penelitian, baik yang terdapat di perpustakaan maupunn yang terdapat dilokasi penelitiandan melalui web di internet. Data primer, adalah data yang lanngsug di kumpulkan oleh peneliti dari sumber pertamanya, yang diperoleh lanngsung melalui wawancara dengan informan penelitian atau warga di desa Hukurila, Kecamatan Leitimur Selatan, kota Ambon. Penentuan informan mengunakan purposive sampling dengan kriteria informan sebagai berikut: Keluarga yang anggota keluarga/istri bekerja sebagai pencari nafkah yaitu berjualan/papalele buahbuahan dan sayur-sayuran di pasar mardika. Keluarga yang anggota keluarga/istri bekerja sebagai pencari nafkah berjualan/papalele ikan segar dan ikan asapan/asar,dua orang. 
Keluarga yang anggota keluarga yaitu anak laki-laki berkerja sebagai tukang ojek dan menjadi supir angkot,dua orang. Keluarga yang anggota keluarga yaitu anak perempuan yang membuat kue dan berjualan dilingkungan desa dan tempat parawisata,masingmasing dua orang. Keluarga yang anggota keluarga yaitu istri dan anak,baik anak laki-laki maupun perempuan membantu suami ke kebun, tiga orang. Keluarga yang anggota keluarga yaitu sebagai pemandu wisata/membantu wisatawan menyelam dengan mengunakan peralatan menyelam,dua orang. Keluarga yang anggota keluarga yaitu istri dan anak perempuan berjualan ditempat wisata, dua orang. Dengan demikian jumlah informan dalam penelitian ini berjumlah lima belas (15) oranng.

\section{Temuan dan Pembahasan.}

Pada masa pandemik Covid 19 yang mewabah dunia dan juga terjadi di Negara Indonesia termasuk Propinsi Maluku dan Kota Ambon, bahkan sampai di Negeri-Negeri dan Desa-Desa, Kelurahan di wilayah Kota Ambon, terutama yang terjadi pada klasterklaster keluarga di Negeri Hukurilla telah membawa perubahan. yang merupakan Negeri adat sedikit demi sedikit kehidupan masyarakatnya sudah terjadi pergeseran. Beberapa fungsi keluarga telah mengalami perubahan. Fungsi-fungsi pokok keluarga yang sangat kelihatan perubahannya diantaranya adalah:

\section{a. Fungsi Biologis}

Keluarga merupakan tempat lahirnya anak-anak, fungsi inilah orang tua melahirkan anak-anak mereka, ini merupakan dasar kelansungan hidup masyarakat. Namun fungsi ini juga mengalami perubahan, karena sekarang keluarga jumlah anak yang sedikit. Kecenderungan kepada jumlah anak yang lebih sedikit dipengaruhi oeleh faktorfaktor:

a. Banyak anak dipandang sebagai hambatan mencapai suksesnya material keluarga.

b. Banyak anak dipandang sebagai hambatan untuk tercapainya kemesrahan keluarga.

c. Meningkatnya aktivitas perempuan di luar rumah sebagai perempuan karier berakibatnya fertilitasnya.

d. Makin sulitnya peluang kerja dimasa pademik covid 19 karena setiap orang harus mematuhi protokol kesehatan.

e. Makin meluasnya pengetahuan dan penggunaan alat-alat kontrasepsi. 
Fungsi ini merupakan tempat seorang anak menumpahkan semua keresahan dan permasalahan yang mereka alami dalam pergaulan dalam masyarakat. Oleh sebab itu dengan keberadaan keluarga akan memberikan rasa aman dan terlindungi dari seorang anak. Akan tetapi sekarang berbeda, justru anak akan lebih terbuka dengan gajetnya yang dia miliki dan berselancar dengan orang-orang baru yang mereka baru kenal dibandingkan dengan keluarganya. Kondisi ini yang mangakibatkan hal yang fatal karena anak akhirnya tidak terbuka dengan orang tuanya. Akibat selanjutnya adalah anak akan dapat terjerumus dalam pergaulan-pergaulan yang menghancurkan sementara orang tua tidak dapat mengontrol perkembangan si anak.

Paparan diatas menunjukkan bahwa respons masyarakat di Negeri Hukurila terhadap adaptasi kehudupan baru dimasa pademik covid 19 terhadap perkembangan kehidupan keluarga dan masyarakat tidak selamanya membawa kebaikan dalam masyarakat. Namun dierah moderen dan pandemik covid yang sekarang melanda dunia ini, justru banyak membawa dampak negatif bagi masyarakat khususnya masyarakat adat yang memiliki kearifan lokal yang sangat luhur dengan nilai-nilai dan tatanan normanorma yang sangat berbudaya.

Disis lain adaptasi kehidupan baru di era modern juga membawa dampak positif sehingga daerah tidak tertinggal dari perkembangan zaman. Masyarakat menjadi melek teknologi dan memberi kemudahan dalam berkomunikasi. Akan tetapi adaptasi kehidupan baru dimasa pandemik dan di era moderen ini, harus selalu disaring sehingga akibat-akibat buruk dari modernisasi dapat di minimalisir.

\section{b. Fungsi Sosialisasi (Pendidikan)}

Keluarga merupakan tempat untuk mendapatkan transpormasi nilai (pendidikan) pertama sampai dengan seorang anak tumbuh dan berkembang menjadi dewasa. Fungsi keluarga tersebut sekarang telah berubah dengan masuknya nilai-nilai baru dari luar akibat modernisasi dan perkembangan teknologi, dan akibat wabah penyakit menular (Covid 19) yang melanda dunia khususnya di Kota Ambon. Hal ini juga berpengaruh pada masa pandemik covid-19 karena pendidikan di Negeri Hukurilla tidak bisa dapat dijalankan secara tatap muka namun dilakukan secara online atau durring sehingga interaksi dan hubungan sosial/pertemanan tidak dapat berjalan karena masing-masing anak mengikuti pendidikan durring dari rumah dengan menggunakan HP android. 
Masyarakat Negeri Hukurilla merupakan wilayah adat yang sangat terbuka sekali dengan perubahan dan perkembangannya, bahkan dalam masyarakat kita jumpai nahwa mereka sudah sangat modern. Kehidupan masyarakatnya sudah maju. Oleh sebab itu, keberadaan HP Android di wilayah ini bukan merupakan hal yang baru dan bukan merupakan sesuatu yang aneh. Hampir semua masyarakat memiliki HP, bahkan sampai dengan anak-anak kecil yang sebenarnya belum layak menggunakan HP android. Kondisi ini yang menimbulkan adanya perubahan fungsi keluarga. Pendidikan dan perkembangan anak terbentuk melalui HP. Orang tua yang seharusnya merupakan media bagi pembentukan mental dan tempat bagi pendidikan anak ternyata mengalami pergeseran. Anak-anak lebih terpengaruh dengan gambar-gambar ataupun tampilan dari HP dibandingkan dengan orang tua.

Perkembangan yang terjadi di Negeri Hukurilla, masuknya teknologi bagi pola pendidikan di wilayah tersebut satu sisi membawa dampak positif, karena dunia anak lebih berkembang dan wawasannya lebih luas karena dengan melihat tampilan di HP maka semua terbuka secara luas pengetahuan dan pemahaman mereka. Akan tetapi di sisi lainnya keberadaan teknologi dan wabah pandemik yang sementara di alami hampir seluruh wilah di Indonesia maka masyarakat bakan keluarga harus beradaptasi dengan kehidupan baru. Bentuk-bentuk nilai positif dari modernisasi bagi pendidikan keluarga adalah seorang anak akan mampu terbuka luas untuk dapat belajar tentang segala sesuatu yang tidak mereka dapatkan dalam keluarga, semua dapat diperoleh di media on line. Akan tetapi disisi lain, nilai-nilai negative seperti gambar-gambar pornografis seorang anak akan mudah sekali untuk mengakses sehingga seorang anak akan mengalami gangguan psikologis karena umur mereka masih belum cukup dewasa untuk merespon apa yang mereka lihat. Akibat negative yang ditemui di Negeri Hukurilla adalah adanya kenakalan remaja di wilayah ini menjadi meningkat. Dari hasil penelitan di lapangan walaupun dalam proses transformasi nilai-nilai terhadap anak-anak dalam keluarga sudah mulai mengalami perubahan dengan adaptasi nilai-nilai baru seperti; keluar rumah harus memakai masker, sering mencuci tangan, jangan bermain berkerumun, menjaga jarak dan tetap berada di dalam rumah. Bahkan respons masyarakat Negeri Hukurila terhadap adaptasi nilai-nilai baru didalam kehidupan keluarga dan masyarakat sangat dipatuhi karena mereka sudah membuat klaster/kelompok keluarga di setiap RT untuk sering 
memantau setiap oarang yang keluar/masuk di Negeri mereka harus melapor di setiap pospos penjagaan.

\section{c. Fungsi Ekonomi}

Keluarga berfungsi sebagai fungsi ekonomi. Ini artinya adalah keluarga bertugas untuk memenuhi kebutuhan keluarga. Anggota keluarga bertugas untuk bekerja dan mendapatkan upah guna memenuhi kebutuhan ekonomi keluarga. Masyarakat Negeri Hukurilla yang merupakan masyarakat adat, tugas ekonomi ini dijalankan oleh seorang ayah, yang bertugas untuk memenuhi kebutuhan ekonomi. Biasanya fungsi ekonomi ini dilakukan oleh laki-laki sebagai kepala keluarga. Seorang laki-laki bekerja sebagai Nelayan dan biasanya ketika mereka melaut dibantu oleh orang lain untuk mendapatkan ikan. Beberapa keluarga juga biasanya mempekerjakan anggota keluarga nya seperti anak laki-lakinya untukikut serta dalam kegiatannya di laut. Namun setelah pandemik covid19 masyarakat Hukurilla mengalami perubahan yang sangat menyolok pada fungsi ekonomi karena fungsi ekonomi didalam keluarga banyak sekali diambil ahli oleh kaum perempuan yang bekerja sebagai papalele di Kota Ambon.

Kondisi di Hukurilla sekarang telah mengalami perubahan, peran ekonomi sekarang dijalankan tidak saja oleh laki-laki akan tetapi juga dijalankan oleh perempuan. Walaupun kondisi ini tidak seutuhnya mengalami perubahan. Peran perempuan di ranah public sebenarnya sudah terjadi sejak dahulu, yang mana perempuan bertugas sebagai papalele untuk menjual hasil tangkapan dari para suami mereka. Akan tetapi sekarang yang terjadi adalah bahwa perempuan tidak saja menjual hasil tangkapan dari suami mereka akan tetapi papalele tersebut telah menjadi pekerjaan mereka. Perempuan menjadi penjual ikan walaupun suaminya tidak menangkap ikan lagi, bahkan banyak perempuan di Negeri Hukurilla yang menjalankan fungsi ekonomi untuk membantu perekonomian keluarga. Sektor-sektor public khususnya di pasar banyak di dominasi oleh perempuan.

Kondisi tersebut juga ditemukan di tempat lain, ketika para suami-suami tidak dapat melaut dan menganggur maka perempuan ikut bekerja untuk mengantikan suami dalam pemenuhan kebutuhan keluarganya. Sebagai contoh: banyak perempuan di Negeri Hukurilla yang berjualan sampai keluar wilayah Hukurilla, misalnya diambon untuk menjual buah buahan, ikan segar, ikan asar/asapan, sayur- sayur seperti sayur daun kasbi, sayur daun melinjo, sayur daun matel dan sayuran has Negeri Hukurila pada waktu musim timur seperti sayur bunga karang yang diambil dari pesisir pantaiyang berkarang. 
Selain itu anak-anak mereka yang sudah dewasa juga membantu orang tua mereka separti anak laki-laki membantu ayah mereka pergi melaut untuk memancing ikan tuna, bila cuaca memungkinkan untuk melaut, ada juga anak laki-laki yang mengojek di kota Ambon. Sedangkan anak perempuan membuat kue untuk berjualan keliling desa dan di tempat wisata. Untuk memenuhi pangan lokal seperti sayur-sayuran masyarakat Negeri Hukurila sudah membuat kelompak-kelompok tani berdasarkan klaster-klaster keluarga di RT masing-masing sehingga mereka sudah membuat sayur organik sayur-sayur yang di tanam di polibek, kemudian sayur tersebut bisa di konsumsi oleh keluarga-keluarga bahkan juga sebagian dijual ke Negeri tetanggan menjadi modal usaha berkelanjutan, beberapa waktu yang lalu di tahun 2020 pemerintah Kota Ambon bapak Walikota dan bapa Kapolda maluku mencanangkan Negeri Hukurila sebagai negeri ketahan pangan.

\section{d. Fungsi Afeksi}

Dalam keluarga terjadi hubungan sosial yang penuh dengan kemesrahan dan afeksi. Hubungan afeksi ini tumbuh sebagai akibat hubungan cinta kasih yang menjadi dasar perkawinan. Dari hubungan cinta kasih ini lahirlah hubungan persaudaraan, persahabatan, kebiasaan identifikasi, persamaan pandangan mengenai nilai-nilai dalam keluarga dan masyarakat. Dasar cinta kasih dan hubungan afeksi ini merupakan faktor penting dalam perkembangan pribadi anak. Dalam masyarakat yang masih memegang tradisi adat dan nilai-nilai agama yang masih kental dan kuat seperti di Negeri Hukurila pribadi sangat membutuhkan hubungan afeksi seperti yang terdapat dalam keluarga, karena suasana afeksi itu tidak terdapat dalam institusi sosial lainnya.

Keluarga adalah memiliki fungsi secara sosial, fungsi keluarga secara sosial ini mendorong keluarga menjalankan fungsinya dalam membentuk anak-anaknya untuk dapat menjalankan perannya dalam masyarakat. Kondisi inilah yang sekarang banylak berubah, modernisasi mengakibatkan masyarakat lebih individual. Individual dalam pengertian bahwa modernisasi teknologi menjadikan fungsi sosial tersebut mengalami pergeseran, seorang anak akan lebih sibuk dengan gajetnya dibandingkan mereka bersosialisasi, bahkan dalam keluarga anak dan orang tua cenderung hubungannya semakin jauh karena semua sudah sibuk dengan gadgednya masing-masing. Kondisi ini yang menjadikan masalah dalam keluarga.

Maraknya media sosial sebagai bentuk modernisasi akan membawa dampak yang tidak baik bagi keutuhan keluarga. Karena masing-masing anggota keluarga akan sibuk 
dengan teman-temannya yang berada jauh dari mereka sementara keluarga dekat dan yag berada dalam satu rumah justru menjauh. Orang mnyebutnya bahwa media sosial akan menjauhkan yang dekat dan mendekatkan yang jauh, bahkan di masa pandemik Covid 19 yang sementara mewabah dunia, Negara Indanesia, Daerah Maluku juga Kota Ambon sehingga semua anggota keluarga bahkan masyarakat harus tetap dirumah dan seluruh kegiatan sosial, pendidikan dan kegiatan beribadah masih tetap melaksanakan protokol kesehatan. Fenomena seperti ini banyak sekali muncul di masyarakat sehingga banyak sekali keretakan dalam keluarga. Hal ini juga terjadi di masyarakat Hukurilla, dunia medsos telah banyak meracuni masyarakatt yang tinggal di wilayah ini sehingga masyarakat yang tinggal di wilayah ini mengalami masalah sosial. Perubahan yang sama terjadi pada keluarga-keluarga yang ada pada Negeri Hukurilla pada masa pandemik covid-19 hubungan kekerabatan atau persaudaraan semakin renggang karena individu atau keluarga tidak bisa berhubungan langsung atau kontak langsung pada acara-acara resepsi keluarga atau acara kedukaan karena negeri Hukurilla sangat ketat melaksanakan aturan protokol covid-19 sesuai dengan anjuran Pemerintah Kota. Hal ini berdampak pada Negeri Hukurilla sehingga sampai sekarang ini Negeri Hukurilla termasuk Negeri yang aman covid-19 atau dengan istilah zona Hijau.

Pada awalnya keluarga merupakan tempat anak mendapatkan pendidikan agama, anak-anak mengetahui tentang nilai-nilai baik dan buruk dari keluarga melalui proses pendidikan dan penanaman nilai-nilai dalam keluarga. Agama dan keluarga memiliki nilai-nilai yang tidak dapat dipisahkan satu dengan yang lainnya. Di Negeri Hukurilla, nilai-nilai agama merupakan satu keyakinan yang yang diyakini oleh masyarakat diwilayah ini walaupun kepercayaan terhadap adat masih diyakini oleh masyarakat yang ada di wilayah ini.

Masyarakat Negeri Hukurilla mengalami perubahan dalam nilai agama yang diyakini, sebagai contoh adalah cara mereka berpakaian ketika mereka akan pergi untuk beribadah. Dahulu masyarakat yang tinggal di wilayah ini ketika akan pergi untuk beribadah mereka pergi tanpa alas kaki dengan menggunakan pakaian serba hitam. Akan tetapi yang terjadi sekarang adalah bahwa masyarakat di Negeri ini pergi dengan menggunakan sepatu dan menggunakan pakaian yang layaknya orang Kota dengan pakaian rapi dan warna yang beraneka ragam, tidak menggunakan warna hitam lagi. Kondisi ini adalah merupakan perubahan yang sangat kentara dan terlihat di wilayah ini. 
Pada masa Pandemik Covid-19 fungsi agama yang berlangsung pada keluarga-keluarga di Negeri Hukurilla dalam mengikuti Ibadah-ibadah hari Minggu keluarga ramai-ramai melakukan kegiatan di gedung Gereja namun pada masa pandemik ini, keluarga-keluarga melakukan Ibadah hanya berlangsung dimasing-masing keluarga atau rumah, begitu juga Ibadah-Ibadah lainnya.

Pada masyarakat Negeri Hukurilla yang merupakan negeri adat memiliki budaya yang sangat erat. Orang tua zaman dahulu selalu menceritakan asal dan sajarah suatu desa atau keturunan secara terus menerus sehingga anak akan tahu asal dan sejarah adanya suatu Negeri. Akan tetapi sekarang yang terjadi pada masyarakat Negeri Hukurilla banyak yang tidak tahu asal dan muasal nya negeri dan keturunan mereka. Masyarakat bahkan sudah tidak mampu menceritakan kembali tentang sejarah desanya. Kondisi inilah yang selanjutnya mamicu konflik karena kepentingan tertentu yang telah bermain diatas hukum adat.

Hal ini tidak terlepas dengan modernisasi yang ada di Negeri Hukurilla. Budaya masyarakat tidak terdokumentasikan dengan baik. Masyarakat mengetahui sejarah hanya berdasarkan dengan budaya tutur yang selanjutnya dituturkan oleh generasi yang tidak mengetahui secara utuh tentang adat di wilayah tersebut. Kondisi ini diperparah dengan kondisi yang sekarang ini berkembang. Masyarakat semakin tidak mengetahui tentang negerinya, komunikasi dalam keluarga yang semakin terbatas menjadikan budaya masyarakat mengalami perubahan. Masyarakat cenderung tidak perduli dengan negerinya, sehingga ketika kepentingan-kepentingan karena kekuasaan bermain maka akan menimmbulkan konflik karena serba ketik jelasan tentang asal muasal atau sejarah yang mereka miliki. Pada masa pandemik keluaraga-keluarga di Negeri Hukurilla mengalami perubahan yang sangat kuat karena budaya bakumpul orang basudara baik antar keluarga dalam negeri maupun bakumpul keluarga/kerabat tidak bisa dilaksanakan karena Negeri Hukurilla sangat ketat melaksanakan aturan protkol kesehatan sesuai anjuran pemerintah Kota Ambon. Hal yang menarik juga muncul kebiasaan baru yang dialami keluargakeluarga di Negeri Hukurilla setiap anggota keluarga mau beraktivitas keluar rumah harus memakai masker dan juga didepan pintu keluarga-keluarga diletakan tempat cuci tangan dan sabun. Ini menunjukan nilai baru yang mungkin bisa membudaya selama pandemik covid-19 ini belum juga hilang. 


\section{e. Fungsi Rekreasi}

Teknologi memiliki dampak positif bagi fungsi rekreasi karena dunia teknologi sebagai bentuk modernisasi menawarkan sarana-sarana hiburan yang cukup menarik bagi masyarakat. Selama ini keluarga menjadi tempat rekreasi dengan menciptakan kebersamaan dan membuat alat-alat yang sederhana sebagai sarana hiburan, akan tetapi sekarang sudah bergeser, kebersamaan keluarga untuk menghabiskan waktu secara bersama-sama telah bergeser. Keluarga sudah tidak berkontribusi besar dalam menciptakan permainan secara bersama dengan media-media yang sangat sederhana. Sebagai contoh: di Negeri Hukurilla terdapat permainan yang dilakukan pada malam hari di halaman rumah, dan pada saat itulah semua anggota keluarga berkumpul untuk sekedar bercerita dan menikmati anak-anak untuk bermain, akan tetapi sekarang masing-masing anggota keluarga telah sibuk dengan gajetnya. Anak-anak cukup duduk sibuk dengan gujetnya dan komunikasi dengan keluarga juga sekedarnya saja. Akibatnya orang tua tidak dapat mengontrol perkembangan dan kejiwaan anak. Bahkan apa yang dilakukan anak orang tua tidak mengetahuinya, dan hal ini dapat berakibat fatal. Bagi Negeri Hukurilla fungsi rekreasi mengalami perubahan yang sangat mencolok karena Negeri Hukurilla merupakan daerah pariwisata sehingga anggota keluarga yang sering memandu wisatawan-wisatawan baik domestik maupun mancanegara tidak dapat dilakukan karena selalu melakukan protokol kesehatan pada masa pandemik ini.

\section{Kesimpulan.}

Beberepa kesimpulan dapat dikemukakan sebagai berikut:

a. Dimasa pandemi covid-19 keluarga-keluarga di Negeri Hukurilla mengalami perubahan fungsi-fungsi Keluarga yang sangat mencolok seperti fungsi biologis, fungsi sosiolisasi, fungsi ekonomi, fungsi afeksi dan fungsi rekreasi.

b. Perubahan-perubahan fungsi keluarga tersebut terlihat karena di Negeri Hukurilla diwajibkan melaksankan Protokol Kesehatan sehingga Negeri Hukurilla yang merupakan daerah wisata megalami perubahan karena Keluarga-keluarga yang berusaha dilokasi wisata tidak bisa berjalan sesuai dengan kebutuhannya.

c. Respons keluarga terhadap kebiasaan baru dimasa pandemik dalam menerima dan menjalankan nilai-nilai baru dalam keluarga dan masyarakat di Negeri Hukurila, sangat dipatuhi misalnya tidak perlu keluar rumah kalau tidak ada keperluan, keluar 
rumah harus menggunakan masker, setiap kali harus mencuci tangan, jangan berkerumun, menjaga jarak kalau ada di tempat-tempat umum atau ruang publik

Negeri Hukurila dimasa pandemik sudah terbentuk kelompok-kelompok tani pada klaster-klaster keluarga ditingkat RT, sehingga masing-masing kelompok sudah menanam sayur mayur di polibek dan sayur hidroponik dan keluarga-keluarga sudah bisa mengkonsumsi sendiri tanpa pergi ke pasar untuk membeli sayur bahkan negeri tetangga juga datang untuk membeli sayur.

\section{Daftar Pustaka.}

Abdullah, I. H. (2011). Sosiologi Pendidikan: Individu, Masyarakat, dan Pendidikan. Jakarta: PT RajaGrafindo Persada.

H.SS, H. K. (2002). SOSIOLOGI KELUARGA. Yogyakarta: Liberty Yogyakarta.

Narwoko, J. D. (2004). SOSIOLOGI: TEKS PENGANTAR \& TERAPAN. Jakarta: PRENADA MEDIA.

Puspitawati, H. 2012. Gender dan Keluarga: Konsep dan Realita di Indonesia. Bogor IPB Press.

Sekanto, Soerjono. 2004. Sosiologi Keluarga. Tentang Ikwal Keluarga,

Remaja dan Anak. Jakarta: Renaka Cipta.

Su'adah, H. (2003). SOSIOLOGI KELUARGA. Malang: Universitas Muhammadiyah Malang.

Sztompka, P. (2004). SOSIOLOGI PERUBAHAN SOSIAL. Jakarta: PRENADA MEDIA. JURNAL. (2018). DIMENSIA Kajian Sosiologi dan Pendidikan. Volume 7, Nomor 1. Yogyakarta: Program Studi Pendidikan Sosiologi Fakultas Ilmu Sosisal Universitas Negeri Yogyakarta berkolaborasi dengan Asosiasi Profesi Pendidik dan Peneliti Sosiologi Indonesia (AP3SI) \& Forum Komunikasi Prog Studi Pendidikan Sosiologi dan Antropologi se-Indonesia. 